\title{
MOTIVASI MAHASISWA AKUNTANSI DAN PENGARUHNYA TERHADAP MINAT UNTUK MENGIKUTI PENDIDIKAN PROFESI AKUNTANSI (Studi Empiris di Fakultas Ekonomi Universitas Mulawarman)
}

\author{
Novy dwi febrianty \\ Muhammad Ikbal \\ Universitas Mulawarman \\ ivaganza@gmail.com
}

\begin{abstract}
The objectives of this study is to examine the effect of motivation on accounting student interest to enroll in an Accounting Profession Education. Motivation are consists of quality motivation, career motivation and economic motivation. Data were obtained using questionnaires distributed to 88 respondents who were chosen as research's sample. The data were analized using multiple regression analysis. The results of this research show that quality motivation and career motivation positively affect accounting student interest to enroll in an Accounting Profession Education while Economic motivation negatively effect on accounting student interest to enroll in an Accounting Profession Education.
\end{abstract}

Keywords: Quality Motivation, Career Motivation, Economic Motivation, Accounting Students Interest

\begin{abstract}
Abstrak: Penelitian ini bertujuan menguji pengaruh motivasi terhadap minat mahasiswa untuk mengikuti Pendidikan Profesi Akuntansi. Motivasi dalam penelitian ini terdiri dari motivasi kualitas, motivasi karir, dan motivasi ekonomi. Data diperoleh dengan menggunakan kuesioner yang disebarkan pada 88 responden sebagai sampel penelitian. Model analisis yang digunakan adalah analisis regresi berganda. Hasil penelitian menunjukkan bahwa motivasi kualitas dan motivasi karir berpengaruh secara positif terhadap minat mahasiswa untuk mengikuti Pendidikan Profesi Akuntansi. Akan tetapi, motivasi ekonomi berpengaruh secara negatif terhadap minat mahasiswa untuk mengikuti Pendidikan Profesi Akuntansi.
\end{abstract}

Kata kunci: Motivasi Kualitas, Motivasi karir, Motivasi Ekonomi, Minat mahasiswa akuntansi

Pendidikan Profesi Akuntansi (PPAk) merupakan pendidikan tambahan yang harus diikuti oleh lulusan sarjana ekonomi jurusan akuntansi yang ingin 
mendapatkan gelar akuntan, sehingga dengan mendapatkan gelar akuntan tersebut yang bersangkutan dapat melanjutkan karir sebagai akuntan publik atau akuntan lainnya. Idealnya suatu program pendidikan akuntansi diharapkan mampu mempersiapkan peserta didiknya untuk memulai dan mengembangkan keanekaragaman karir profesional dalam bidang akuntansi, sehingga dengan adanya Pendidikan Profesi Akuntansi (PPAk) tersebut dapat menciptakan tenaga profesional yang berkualitas, mampu bersaing dan memiliki keunggulan kompetitif.

Mengingat pentingnya keberadaan Pendidikan Profesi Akuntansi (PPAk) bagi mahasiswa akuntansi maka diperlukan motivasi dalam diri mahasiswa untuk mengikuti Pendidikan Profesi Akuntansi (PPAk). Diharapkan dengan mengikuti Pendidikan Profesi AKuntansi (PPAk) dapat membantu menciptakan akuntanakuntan yang professional.

Menurut Lubis (2010) motivasi adalah proses yang dimulai dengan definisi fisiologis atau psikologis yang menggerakan perilaku atau dorongan yang ditunjukan untuk tujuan insentif. Terdapat keyakinan bahwa perilaku manusia ditimbulkan oleh motivasi. Dengan demikian, ada sesuatu yang mendorong (memotivasi) seseorang untuk berbuat sesuatu. Sementara menurut Hayati (2007) motivasi adalah konsep yang dipakai untuk menguraikan keadaan ekstrinsik yang menstimulasi perilaku tertentu dan respon instrinsik yang ditampilkan dalam perilaku. Respon intrinsik disebut juga sebagai motif (pendorong) yang mengarahkan perilaku ke arah perumusan kebutuhan atau pencapaian tujuan. Stimulasi ekstrinsik dapat berupa hadiah atau insentif, mendorong individu melakukan atau mencapai sesuatu. Jadi motivasi adalah interaksi instrinsik dan ekstrinsik yang dapat dilihat berupa perilaku atau penampilan.

Motivasi berperan sentral sebagai sesuatu yang menyebabkan, menyalurkan dan mendukung perilaku manusia, supaya mau bekerja giat dan antusias mencapai hasil yang optimal. Motivasi banyak dikaitkan dengan timbulnya minat. Minat adalah sesuatu yang pribadi dan berhubungan erat dengan sikap. Minat dan sikap merupakan dasar bagi prasangka, dan minat juga penting dalam mengambil keputusan. Minat dapat menyebabkan seseorang giat melakukan sesuatu yang 
telah menarik minatnya. Dalam penelitian ini, motivasi dipandang sebagai dorongan/tenaga yang menggerakkan mahasiswa untuk berminat mengikuti PPAk. Penelitian Benny dan Yuskar (2006) serta penelitian Widyastuti, dkk (2004) misalnya, menunjukan bahwa motivasi berperan dalam menentukan minat seorang mahasiswa untuk mengikuti Pendidikan Profesi Akuntansi (PPAk).

Permasalahan yang secara empiris dapat diamati hingga saat ini adalah tidak semua mahasiswa memiliki minat atau keinginan yang tinggi untuk mengikuti Pendidikan Profesi Akuntansi. Efek yang kemungkinan muncul dari rendahnya minat ini adalah minimnya jumlah lulusan Pendidikan Profesi Akuntansi sehingga berimbas pada minimnya tenaga kompetitif yang akan bekerja di Kantor Akuntan Publik atau yang membuka Kantor Akuntan Publik. Oleh karena itu tujuan dari penelitian ini adalah untuk menguji pengaruh motivasi terhadap minat seseorang untuk mengikuti PPAk.

Terdapat beberapa dimensi motivasi yang meliputi motivasi kualitas, motivasi karir, dan motivasi ekonomi. Motivasi kualitas adalah dorongan yang timbul dari dalam diri seseorang untuk memiliki dan meningkatkan kualitas diri dan kemampuannya dalam bidang yang ditekuninya sehingga dapat melaksanakan tugas dengan baik dan benar. Kajian yang telah dilakukan oleh Benny dan Yuskar (2006) di Perguruan Tinggi di Kota Padang menghasilkan kesimpulan bahwa motivasi kualitas mempunyai pengaruh yang signifikan terhadap minat mahasiswa mengikuti Pendidikan Profesi Akuntansi (PPAk). Hal ini dapat disebabkan karena adanya dorongan dalam diri mahasiswa tersebut untuk memiliki dan meningkatkan kualitas diri dan kemampuannya dalam bidang yang ditekuninya.

$\mathrm{H}_{1}$ :Motivasi kualitas berpengaruh positif terhadap minat mahasiswa dalam mengikuti Pendidikan Profesi Akuntansi (PPAk).

Motivasi karir adalah dorongan yang timbul dalam diri sesorang untuk meningkatkan kemampuan pribadinya dalam rangka mencapai kedudukan, jabatan atau karir yang lebih baik dari sebelumnya. Profesi akuntan publik merupakan salah satu pilihan karir yang banyak diminati oleh mahasiswa 
akuntansi, hal ini dibuktikan oleh penelitian Wijayanti (2000) dalam Benny dan Yuskar (2006) yang menyatakan bahwa mahasiswa akuntansi yang memilih karir sebagai akuntan publik mengharapkan gaji awal yang tinggi, memperoleh kesempatan berkembang yang lebih baik dibandingkan dengan karir yang lain serta memperoleh pengakuan atas prestasi yang telah diraih.

Pilihan karir merupakan ungkapan diri seseorang, karena pilihan karir menunjukkan motivasi seseorang, ilmu, kepribadian dan seluruh kemampuan yang dimiliki. Institusi pendidikan mempunyai pengaruh besar terhadap perkembangan karir seorang akuntan. Sebagai sebuah pendidikan profesi, Pendidikan Profesi Akuntansi (PPAk) dapat memberikan kontribusi positif untuk mahasiswa yang ingin mengembangkan kemampuan di bidang akuntansi secara teknis dan profesional.

Siegel, Blank, dan Rigsby (1991) melakukan penelitian untuk mengetahui hubungan antara struktur organisasi institusi pendidikan dengan perkembangan profesional selanjutnya bagi auditor. Penelitian tersebut menunjukkan bahwa struktur organisasi mempunyai pengaruh signifikan terhadap perkembangan profesi selanjutnya. Auditor yang mempunyai latar belakang pendidikan pofesional akuntansi membutuhkan waktu yang lebih sedikit untuk dipromosikan menjadi auditor senior dan atau manajer.

Hasil penelitian Lisnasari dan Fitriany (2008) yang dilakukan di Fakultas Ekonomi Universitas Indonesia menunjukan bahwa secara keseluruhan motivasi karir dan motivasi mengikuti Ujian Sertifikasi Akuntan Publik (USAP) merupakan faktor yang signifikan mempengaruhi minat mahasiswa untuk mengikuti Pendidikan Profesi Akuntansi (PPAk).

$\mathrm{H}_{2}$ : Motivasi karir berpengaruh positif terhadap minat mahasiswa untuk mengikuti Pendidikan Profesi Akuntansi (PPAk). 
Motivasi ekonomi dapat diartikan sebagai suatu dorongan yang timbul dalam diri seseorang untuk meningkatkan kemampuan pribadinya dalam rangka mencapai penghargaan finansial dan kemampuan ekonominya.

Penghargaan finansial merupakan salah satu bentuk sistem pengendalian manajemen.Untuk memastikan bahwa segenap elemen karyawan dapat mengarahkan tindakannya terhadap pencapaian tujuan perusahaan, maka manajemen memberikan balas jasa atau reward dalam berbagai bentuk, termasuk di dalamnya finansial reward.Secara umum penghargaan finansial terdiri atas penghargaan langsung dan tidak langsung.Penghargaan langsung dapat berupa pembayaran dari upah dasar atau gaji pokok, gaji dari lembur, pembagian dari laba.Sedangkan penghargaan tidak langsung meliputi asuransi, tunjangan biaya sakit, program pensiun.

Carpenter dan Strawser (1970) melakukan penelitian untuk mengetahui kriteria mahasiswa jurusan akuntansi pada tingkat akhir di Pennsylvania State University dalam memilih karir. Hasil penelitian tersebut menunjukkan bahwa sifat pekerjaan, kesempatan promosi, dan gaji awal merupakan tiga karakter terpenting dalam pemilihan karir di antara sebelas faktor pekerjaan.

Benny dan Yuskar (2006) menyatakan bahwa berkarir di Kantor Akuntan Publik (KAP) merupakan suatu karir yang memberikan penghargaan secara finansial dan pengalaman bekerja yang bervariasi. Berkarir di Kantor Akuntan Publik (KAP) dapat menghasilkan pendapatan yang tinggi dibandingkan dengan pendapatan yang diperoleh dari karir yang lain. Hal ini juga dibuktikan oleh penulisan Wijayanti (2000) dalam Benny dan Yuskar (2006) yang menyatakan bahwa salah satu harapan mahasiswa akuntansi yang memilih karier sebagai akuntan publik yaitu gaji awal yang tinggi.

Albrecht dan Sack (2000) menyatakan bahwa salah satu penyebab menurunnya jumlah mahasiswa akuntansi selama kurun waktu 1995 hingga 1999 yang mencapai $23 \%$ adalah akibat lebih rendahnya gaji awal pada profesi jika dibandingkan dengan tahun-tahun sebelumnya.

$\mathrm{H}_{3}$ :Motivasi ekonomi berpengaruh positif terhadap minat mahasiswa untuk mengikuti Pendidikan Profesi Akuntansi (PPAk). 
Berdasarkan uraian di atas maka hubungan antar variabel dapat digambarkan sebagai berikut:

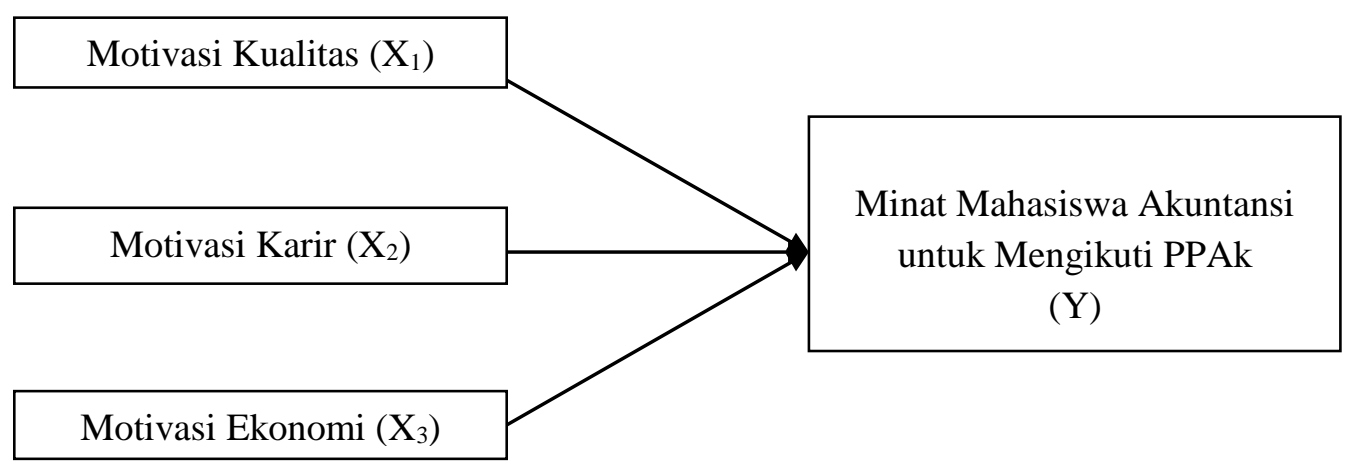

Gambar 1. Pengaruh Variabel Bebas terhadap Variabel Terikat

\section{METODE}

Populasi dalam penelitian ini adalah seluruh mahasiswa strata satu (S1) jurusan akuntansi baik mahasiswa strata satu (S1) akuntansi reguler maupun strata satu (S1) akuntansi non reguler serta mahasiswa alih jenjang (AJ) jurusan akuntansi yang masih aktif dalam rentang tahun angkatan 2008-2010 yang telah menempuh mata kuliah auditing yaitu sebanyak 753 mahasiswa.

Teknik pengambilan sampel menggunakan metode proportionate stratified random sampling. Proportionate stratified random sampling adalah metode penarikan sampel acak secara proporsional untuk satu kelompok strata dalam populasi. Sampel dihitung dengan menggunakan rumus Slovin yang menggunakan nilai kritis sebesar 0,10 sehingga dihasilkan jumlah sampel sebanyak 88 mahasiswa.

Metode pengumpulan data dalam penelitian ini adalah kuesioner. Kuesioner dalam penelitian ini adalah untuk mengukur motivasi kualitas, motivasi karir, motivasi ekonomi dan minat mahasiswa akuntansi untuk mengikuti Pendidikan Profesi Akuntansi (PPAk) yang terdiri dari 35 item pernyataan. Berdasarkan uji validitas dan reliabilitas instrumen diketahui bahwa semua item pernyataan dalam kuesioner telah valid dan reliabel. Adapun metode analisis data dalam penelitian 
ini adalah analisis regresi berganda. Sebelumnya dilakukan uji normalitas dan heterokedastisitas untuk memastikan bahwa data dapat dianalisis dengan teknik regresi berganda.

Dalam penelitian ini, minat mahasiswa akuntansi untuk mengikuti Pendidikan Profesi Akuntansi (PPAk) diartikan sebagai keinginan yang didorong oleh suatu keinginan setelah melihat, mengamati dan membandingkan serta mempertimbangkan dengan kebutuhan yang diinginkan berkaitan dengan Pendidikan Profesi Akuntansi (PPAk) (Widyastuti, dkk, 2004). Minat untuk mengikuti Pendidikan Profesi Akuntansi (PPAk) ini terdiri dari 5 item pernyataan dan diukur dengan menggunakan skala likert dari (1) sampai (5).

Motivasi kualitas diartikan sebagai dorongan yang timbul dalam diri seseorang untuk memiliki dan meningkatkan kualitas atau kemampuannya dalam melaksanakan tugasnya dengan baik dan benar (Widyastuti, dkk, 2004). Motivasi kualitas diukur dengan skala (1) sampai (5). Variabel independen dari motivasi kualitas ini terdiri dari 10 item pernyataan. Selanjutnya, motivasi karir adalah dorongan yang timbul dari dalam diri seseorang untuk meningkatkan kemampuan pribadinya dalam rangka mencapai karir yang lebih baik dari sebelumnya (Widyastuti, dkk, 2004).Motivasi karir diukur dengan skala (1) sampai (5)dan terdiri dari 10 item pernyataan. Motivasi ekonomi adalah suatu dorongan yang timbul dari dalam diri seseorang untuk meningkatkan kemampuan pribadinya dalam rangka mencapai penghargaan finansial yang diinginkan (Widyastuti, dkk, 2004).Motivasi ekonomi diukur dengan skala (1) sampai (5). Variabel independen dari motivasi ekonomi ini terdiri dari 10 item pernyataan.

\section{HASIL DAN PEMBAHASAN}

\section{Hasil}

Sebelum dilakukan regresi berganda, dilakukan uji normalitas dan heterokedastisitas terhadap data. Dari hasil perhitungan uji Kolmogorov-Smirnov dapat diketahui bahwa $p$-value dari Unstandardized residual ternyata lebih besar dari $>0,05$, sehingga keseluruhan data tersebut dinyatakan memiliki distribusi normal atau memiliki sebaran data yang normal. Dari hasil perhitungan 
menunjukkan bahwa tidak ada gangguan heteroskedastisitas, karena nilai signifikansi korelasi lebih besar dari 0,05 (>0,05). Secara keseluruhan tidak ada masalah heteroskedastisitas dalam penelitian ini.

Dari analisis regresi berganda didapatkan persamaan regresi berikut.

$$
\mathrm{Y}=0,428 \mathrm{X}_{1}+0,444 \mathrm{X}_{2}+(-0,063) \mathrm{X}_{3}+\mathrm{e}
$$

Koefisien $\left(\beta_{1}\right)=0,428$ menunjukkan bahwa motivasi kualitas $\left(\mathrm{X}_{1}\right)$ berpengaruh positif terhadap minat mahasiswa akuntansi untuk mengikuti PPAk (Y). Koefisien $\left(\beta_{2}\right)=0,444$ menunjukkan bahwa motivasi karir $\left(\mathrm{X}_{2}\right)$ berpengaruh positif terhadap minat mahasiswa akuntansi untuk mengikuti PPAk $(Y)$. Koefisien $\left(\beta_{3}\right)=-0,06$ menunjukkan bahwa motivasi ekonomi $\left(\mathrm{X}_{3}\right)$ berpengaruh negatif terhadap minat mahasiswa akuntansi untuk mengikuti PPAk (Y).

Berdasarkan output analisis determinasi $\left(\mathrm{R}^{2}\right)$ diperoleh angka Adjusted $R^{2}$ sebesar 0,467 atau 46,7\%. Hal ini menunjukkan bahwa persentase sumbangan pengaruh variabel independen (motivasi kualitas, motivasi karir dan motivasi ekonomi) terhadap variabel dependen (minat mahasiswa akuntansi untuk mengikuti Pendidikan Profesi Akuntansi (PPAk)) sebesar 46,7\%. Atau variasi variabel independen (motivasi kualitas, motivasi karir dan motivasi ekonomi) yang digunakan dalam model mampu menjelaskan sebesar 46,7\% variasi variabel dependen (minat mahasiswa untuk mengikuti Pendidikan Profesi Akuntansi (PPAk)). Sedangkan sisanya sebesar 53,3\% dipengaruhi atau dijelaskan oleh variabel lain yang tidak dimasukan dalam model penelitian ini.

Selain itu diketahui bahwa $F_{\text {hitung }}=27,400$ sedangkan $F_{\text {tabel }} 2,713$ pada taraf signifikansi $5 \%$. Oleh karena $F_{\text {hitung }}>F_{\text {tabel }}(27,400>2,713)$ maka model regresi tersebut layak. Nilai $t_{\text {hitung }}>t_{\text {tabel }}(5,074>1,988)$ dan signifikansi $(0,000<0,05)$ maka Ha diterima, artinya bahwa ada pengaruh secara signifikan antara motivasi kualitas dan minat mahasiswa akuntansi untuk mengikuti Pendidikan Profesi Akuntansi (PPAk). Oleh karena $t_{\text {hitung }}$ bernilai positif, maka memiliki arti bahwa motivasi kualitas berhubungan positif dan signifikan terhadap minat mahasiswa akuntansi untuk mengikuti Pendidikan Profesi Akuntansi (PPAk).

Nilai $t_{\text {hitung }}>t_{\text {tabel }}(4,521>1,988)$ dan signifikansi $(0,000<0,05)$ maka Ha diterima, artinya bahwa ada pengaruh secara signifikan antara motivasi karir dan 
minat mahasiswa akuntansi untuk mengikuti Pendidikan Profesi Akuntansi (PPAk). Oleh karena thitung bernilai positif, maka memiliki arti bahwa motivasi kualitas berhubungan positif dan signifikan terhadap minat mahasiswa akuntansi untuk mengikuti Pendidikan Profesi Akuntansi (PPAk).

Nilai $t_{\text {hitung }}<t_{\text {tabel }}(-0,690<1,988)$ dan signifikansi $(0,492>0,05)$ maka Ha ditolak, artinya bahwa tidak ada pengaruh secara signifikan antara motivasi ekonomi dan minat mahasiswa akuntansi untuk mengikuti Pendidikan Profesi Akuntansi (PPAk).

\section{Pembahasan}

Dari pengujian analisis regresi linier berganda yang telah diuraikan sebelumnya diketahui bahwa nilai signifikansi variabel motivasi kualitas adalah 0,000 (lebih kecil dari $\alpha=5 \%$ ) serta nilai $t_{\text {hitung }}$ bernilai positif. Hal ini menunjukkan bahwa motivasi kualitas mempunyai pengaruh positif dan signifikan terhadap minat mahasiswa akuntansi untuk mengikuti Pendidikan Profesi Akuntansi (PPAk).

Hasil ini mendukung hipotesis pertama $\left(\mathrm{H}_{1}\right)$ yang diajukan, yaitu motivasi kualitas berpengaruh positif terhadap minat mahasiswa akuntansi untuk mengikuti Pendidikan Profesi Akuntansi (PPAk). Hasil penelitian ini tidak sejalan dengan hasil penelitian yang dilakukan sebelumnya oleh Widyastuti, dkk (2004). Hal ini mungkin disebabkan karena perbedaan objek penelitian dan jumlah sampel yang diteliti antara penulis dan peneliti terdahulu. Perbedaan hasil ini juga kemungkinan disebabkan karena program Pendidikan Profesi Akuntansi (PPAk) ini sudah dikenal oleh mahasiswa akuntansi pada saat sekarang dibandingkan pada waktu peneliti terdahulu melaksanakan penelitian ini dimana Pendidikan Profesi Akuntansi (PPAk) baru mulai dikenal oleh mahasiswa akuntansi. Hal ini mungkin juga disebabkan karena adanya tuntutan transparansi di pasar modal yang merupakan salah satu prinsip dari Good Corporate Govermance (GCG) menjadi dorongan bagi mahasiswa akuntansi untuk meningkatkan kualitas diri dan kemampuannya agar mampu bersaing didunia kerja. 
Untuk variabel motivasi karir $\left(\mathrm{X}_{2}\right)$ diketahui bahwa nilai signifikansinya adalah 0,000 (lebih kecil dari $\alpha=5 \%$ ) serta nilai thitung bernilai positif. Hal ini menujukan bahwa motivasi karir mempunyai pengaruh positif dan signifikan terhadap minat mahasiswa akuntansi untuk mengikuti Pendidikan Profesi Akuntansi (PPAk).

Hasil ini mendukung hipotesis kedua $\left(\mathrm{H}_{2}\right)$ yang diajukan yaitu motivasi karir berpengaruh positif dan signifikan terhadap minat mahasiswa akuntansi untuk mengikuti Pendidikan Profesi Akuntansi (PPAk). Hasil pengujian ini sejalan dengan hasil penelitian yang dilakukan sebelumnya oleh Widyastuti, dkk (2004), Benny dan Yuskar (2006) dan Lisnasari dan Vitriany (2008). Hal ini dapat disebabkan karena adanya harapan peningkatan karir mahasiswa dimasa depan. Mahasiswa yang ingin meningkatkan dan mengembangkan karir memiliki anggapan bahwa Pendidikan Profesi Akuntansi (PPAk) merupakan salah satu jembatan untuk mencapai karir yang lebih baik. Disamping itu, hal ini dapat disebabkan karena mahasiswa beranggapan bahwa karir yang semakin tinggi lebih penting sehingga mampu mendorong mahasiswa untuk mengikuti Pendidikan Profesi Akuntansi (PPAk) agar dapat mencapai kedudukan yang lebih tinggi didalam pekerjaannya, memperoleh kesempatan berkembang yang lebih baik, membutuhkan lebih sedikit waktu untuk dipromosikan serta memperoleh pengakuan atas prestasi yang diraih.

Untuk variabel motivasi ekonomi $\left(\mathrm{X}_{3}\right)$ diketahui nilai signifikansi adalah 0,492 (lebih besar dari $\alpha=5 \%$ ) serta nilai thitung bernilai negatif. Hal ini menunjukan bahwa motivasi ekonomi tidak berpengaruh signifikan terhadap minat mahasiswa akuntansi untuk mengikuti Pendidikan Profesi Akuntansi (PPAk). Hasil ini tidak mendukung hipotesis ketiga $\left(\mathrm{H}_{3}\right)$ yang diajukan, yaitu motivasi ekonomi berpengaruh positif dan signifikan terhadap minat mahasiswa akuntansi untuk mengikuti Pendidikan Profesi Akuntansi (PPAk). Dengan demikian, hasil pengujian ini sejalan dengan hasil penelitian yang dilakukan sebelumnya oleh Widyastuti, dkk (2004), Lisnasari dan Vitriany (2008) serta Benny dan Yuskar (2006). Hal ini dapat disebabkan karena faktor dalam diri mahasiswa tersebut yang tidak terdorong untuk mencari penghargaan finansial 
atau ekonomi tetapi lebih terdorong untuk mengerjakan sesuatu yang lebih disukai daripada bekerja hanya karena imbalan. Menurut Benny dan Yuskar (2006) hal ini mungkin disebabkan karena berkarir dibidang lain memberikan penghasilan yang lebih tinggi atau lebih besar daripada berkarir sebagai akuntan. Sedangkan menurut Lisnasari dan Vitriany (2008), hal ini mungkin juga disebabkan karena biaya untuk mengikuti Pendidikan Profesi Akuntansi (PPAk) mahal sehingga mahasiswa kurang berminat mengikuti Pendidikan Profesi Akuntansi (PPAk) dan mungkin akan lebih memilih untuk mengikuti program pascasarjana (S2).

Temuan-temuan dalam penelitian ini memiliki implikasi yang penting bagi pengembangan program Pendidikan Profesi Akuntansi (PPAk) itu sendiri, bahwa motivasi kualitas dan motivasi karir mempengaruhi minat mahasiswa akuntansi untuk mengikuti Pendidikan Profesi Akuntansi (PPAk). Hal ini menunjukan bahwa keinginan untuk terjun lebih jauh dalam bidang akuntansi dengan mengikuti Pendidikan Profesi Akuntansi (PPAk) setidaknya didasari oleh niat untuk meningkatkan kualitas diri dan untuk meningkatkan karir kearah yang lebih baik.

Dalam era globalisasi ini, dunia akuntansi sangat dituntut profesionalismeannya.Untuk memajukan bidang ini, Pendidikan Profesi Akuntansi (PPAk) harus juga meningkatkan mutunya dalam menanggapi tantangan ini. Penelitian ini menyumbangkan hasil yang mencoba mengatakan bahwa mahasiswa akuntansi yang ingin mengikuti Pendidikan Profesi Akuntansi (PPAk) berharap banyak kepada institusi penyelenggara Pendidikan Profesi Akuntansi (PPAk) untuk mampu memberikan kurikulum yang dapat meningkatkan kualitas diri mahasiswa akuntansi serta meningkatkan karir mahasiswa akuntansi.

Selain itu, temuan dalam penelitian ini berguna bagi calon lulusan akuntansi untuk mengetahui tentang arti pentingnya program Pendidikan Profesi Akuntansi (PPAk) dalam rangka untuk meningkatkan ke-profesionalisme-an mahasiswa dalam bidang akuntansi.Selain itu, peningkatan kegiatan promosi dan sosialiasai mengenai arti pentingnya Pendidikan Profesi Akuntansi (PPAk) harus dilakukan oleh penyelenggara Pendidikan Profesi Akuntansi (PPAk) agar dapat 
meningkatkan pemahaman mengenai arti pentingnya Pendidikan Profesi Akuntansi (PPAk) sehingga meningkatkan minat mereka untuk mengikuti program pendidikan tersebut.

Hambatan-hambatan berupa kurangnya pengetahuan mahasiswa mengenai profesi akuntan, adanya Undang-undang (UU) nomor 5 tahun 2011 tentang akuntan publik yang mana isinya mengatur tentang diberlakukannya denda sebesar Rp 300.000.000 (tiga ratus juta rupiah) jika seorang akuntan menyalahi etika keprofesiannya serta tidak terdapatnya Kantor Akuntan Publik yang berlokasi di Samarinda mungkin merupakan faktor-faktor yang membuat menurunnya minat mahasiswa akuntansi untuk mengikuti program Pendidikan Profesi Akuntansi (PPAk) dan berkiprah dibidang akuntan ini. Oleh sebab itu, sangat diharapkan arahan, masukan serta bimbingan dari lembaga-lembaga terkait keprofesian akuntan untuk bagaimana mensiasati atau menanggulangi hambatanhambatan tersebut guna meningkatkan minat mahasiswa akuntansi untuk mengikuti program Pendidikan Profesi Akuntansi (PPAk).

\section{SIMPULAN}

Berdasarkan hasil penelitian di atas, maka dapat disimpulkan hal-hal berikut. (1) Dari hasil pengujian hipotesis pertama $\left(\mathrm{H}_{1}\right)$ dapat disimpulkan bahwa motivasi kualitas mempengaruhi secara positif dan signifikan terhadap minat mahasiswa akuntansi untuk mengikuti Pendidikan Profesi Akuntansi (PPAk). (2) Dari hasil pengujian hipotesis kedua $\left(\mathrm{H}_{2}\right)$ dapat disimpulkan bahwa motivasi karir mempengaruhi secara positif dan signifikan terhadap minat mahasiswa akuntansi untuk mengikuti Pendidikan Profesi Akuntansi (PPAk). (3) Dari hasil pengujian hipotesis ketiga $\left(\mathrm{H}_{3}\right)$ dapat disimpulkan bahwa motivasi ekonomi tidak berpengaruh secara signifikan terhadap minat mahasiswa akuntansi untuk mengikuti Pendidikan Profesi Akuntansi (PPAk).

Dengan demikian, secara keseluruhan kesimpulan yang dapat diambil dalam penelitian ini adalah motivasi kualitas dan motivasi karir berpengaruh signifikan terhadap minat mahasiswa akuntansi untuk mengikuti Pendidikan Profesi 
Akuntansi (PPAk). Sedangkan motivasi ekonomi tidak berpengaruh signifikan terhadap minat mahasiswa akuntansi untuk mengikuti Pendidikan Profesi Akuntansi (PPAk).

Penelitian ini memiliki beberapa keterbatasan yaitu pertama, minat untuk mengikuti Pendidikan Profesi Akuntansi (PPAk) hanya ditinjau dari motivasi kualitas, motivasi karir dan motivasi ekonomi yang mungkin masih ada hal-hal lain yang terkait seperti motivasi berprestasi dan motivasi sosial mahasiswa yang ditinjau dari keinginan mahasiswa untuk memiliki prestasi yang tinggi dalam pekerjaannya dan keinginan mahasiswa untuk mendapatkan pengakuan dan penghargaan dari lingkungan dimana mahasiswa tersebut berada. Kedua, faktor biaya pendidikan dan lamanya pendidikan belum dikaji lebih jauh. Padahal ada kemungkinan bahwa faktor-faktor seperti biaya pendidikan dan lamanya pendidikan akan mempengaruhi minat mahasiswa akuntansi untuk mengikuti Pendidikan Profesi Akuntansi (PPAk). Ketiga, faktor pemahaman mahasiswa akuntansi mengenai keunggulan dan kekhususan program Pendidikan Profesi Akuntansi (PPAk) mungkin juga akan mempengaruhi minat mahasiswa akuntansi untuk mengikuti Pendidikan Profesi Akuntansi (PPAk). Namun, faktor tersebut belum dilakukan pengkajiannya.

Untuk itu, peneliti menyarankan kepada peneliti selanjutnya yaitu: (1) Peneliti selanjutnya diharapkan dapat membandingkan antara motivasi mahasiswa peserta Pendidikan Profesi Akuntansi (PPAk) dan motivasi mahasiswa akuntansi tingkat akhir agar dapat diketahui perbedaannya, (2) Peneliti selanjutnya diharapkan dapat menambah variabel penelitian yang meliputi motivasi berprestasi, biaya pendidikan serta lamanya pendidikan maupun faktor-faktor lain yang mungkin mempengaruhi minat mahasiswa akuntansi untuk mengikuti Pendidika Profesi Akuntansi (PPAk), (3) Pada penelitian selanjutnya, peneliti dapat menggunakan metode tanya jawab langsung atau secara lisan terhadap responden dengan meminta jawaban secara tulisan. Hal ini diharapkan mampu memberikan hasil yang lebih bervariasi. 


\section{DAFTAR RUJUKAN}

Albrect, W.R. Sack. 2000. Accounting Education: Charting the course through a perilous future. Accounting Education Series. 16. Saratosa, FL: American Accounting Association

Benny, Ellya dan Yuskar. 2006. Pengaruh Motivasi terhadap Minat Mahasiswa Akuntansi Untuk Mengikuti Pendidikan Profesi Akuntansi (PPAk). Simposium Nasional Akuntansi IX.

Carpenter, C.G., Strawser. 1970. Job selection preferences of accounting students. Journal of Accountancy. June: 84-86

Gultom, Atahasi. 2007. Pengaruh Motivasi Kualitas, Motivasi Ekonomi dan Motivasi Karir Terhadap Minat Mahasiswa Peserta Pendidikan Profesi Akuntansi (PPAk). Universitas Bengkulu. Bengkulu.

Handhika, Anggara Yudha. 2010. Persepsi Mahasiswa Akuntansi terhadap Faktor-faktor Pemilihan Karir Akuntan Publik dan Non Akuntan Publik. Universitas Pembangunan Nasional "Veteran". Jawa Timur.

Hartono, Jogiyanto. 2004. Metodologi Penelitian Bisnis : Salah Kaprah dan Pengalaman-pengalaman, Edisi 2004/2005, BPFE, Yogyakarta.

Hayati, Rahmah Nur. 2007. Pengaruh Pengetahuan, Sikap dam Motivasi terhadap Minat Bidan Mengikuti Uji Kompetensi di Kota Semarang Tahun 2007. Program Pascasarjana Universitas Diponegoro. Semarang. http://fe.unmul.ac.id diakses pada tanggal 31 Januari 2012.

Ikbal, Muhammad. 2011. Pengaruh Motivasi Terhadap Minat Mahasiswa Mahasiswa Akuntansi untuk Mengikuti Pendidikan Profesi Akuntansi : Studi Kasus pada Mahasiswa Akuntansi Universitas Diponegoro. Semarang.

Lisnasari, Riani Nurainah, dan Fitriany. 2008. Faktor-faktor yang Mempengaruhi Minat Mahasiswa Akuntansi untuk Mengikuti Pendidikan Profesi Akuntansi. The 2nd Accounting Conference, 1st Doctoral Colloquium, and Accounting Workshop, 4-5 November 2008.

Lubis, Arfan Ikhsan. 2010. Akuntansi Keperilakuan, Edisi Kedua. Salemba Empat. Jakarta.

Mahmud, Amir. 2008. Pengaruh Motivasi Terhadap Minat Mahasiswa untuk Mengikuti Pendidikan Profesi Akuntansi. Jurnal Pendidikan Ekonomi Vol. 3 No.1 Februari. UNES.

Siegel, Philip H., Blank, Mark M. Rigsby, John T. 1991. Socialisation of the Accounting Professional: Evidence of Treatment Effect on Subsequent Auditor Performance. Accounting, Auditing, and Accountability Journal

Priyatno, Duwi. 2010. Paham Analisis Statistik Data Dengan SPSS.MediaKom. 
Tengker, Victor S.G. dan Jenny Morasa. 2007. Pengaruh Motivasi Karir Terhadap Minat Mahasiswa Akuntansi untuk Mengikuti Pendidikan Profesi Akuntansi (Studi pada Jurusan Akuntansi FE Unsrat Manado). Manado.

Widyastuti, Suryaningrum dan Juliana. 2004. Pengaruh Motivasi terhadap Minat Mahasiswa Akuntansi Untuk Mengikuti Pendidikan Profesi Akuntansi. Simposium Nasional Akuntansi VII.www.iaiglobal.or.id diakses pada tanggal 20 November 2011.www.wikipedia.com diakses pada tanggal 11 Desember 2011. 